\title{
Arecoline Hydrobromide Enhances Jejunum Smooth Muscle Contractility via Voltage-Dependent Potassium Channels in $\mathbf{W} / \mathbf{W}^{\mathbf{v}}$ Mice
}

\author{
Qicheng CHEN ${ }^{1}$, Zhi JIANG ${ }^{1}$, Junhong ZHANG ${ }^{1}$, Lixing CAO ${ }^{1}$, Zhiqiang CHEN ${ }^{1}$ \\ ${ }^{1}$ The Research Team of Traditional Chinese Medicine Applications of Perioperative, The Second \\ Affiliated Hospital of Guangzhou University of Chinese Medicine, Guangzhou, Guangdong, China
}

Received August 10, 2020

Accepted March 4, 2021

Epub Ahead of Print May 12, 2021

\begin{abstract}
Summary
Gastrointestinal motility was disturbed in $\mathrm{W} / \mathrm{W}^{\mathrm{v}}$, which were lacking of interstitial cells of Cajal (ICC). In this study, we have investigated the role of arecoline hydrobromide (AH) on smooth muscle motility in the jejunum of $\mathrm{W} / \mathrm{W}^{2}$ and wild-type (WT) mice. The jejunum tension was recorded by an isometric force transducer. Intracellular recording was used to identify whether $\mathrm{AH}$ affects slow wave and resting membrane potential (RMP) in vitro. The whole-cell patch clamp technique was used to explore the effects of $\mathrm{AH}$ on voltage-dependent potassium channels for jejunum smooth muscle cells. $\mathrm{AH}$ enhanced $\mathrm{W} / \mathrm{W}^{\mathrm{v}}$ and WT jejunum contractility in a dose-dependent manner. Atropine and nicardipine completely blocked the excitatory effect of $\mathrm{AH}$ in both W/Wv and WT. TEA did not reduce the effect of AH in WT, but was sufficient to block the excitatory effect of $A H$ in $W / W^{v}$. AH significantly depolarized the RMP of jejunum cells in W/W and WT. After pretreatment with TEA, the RMP of jejunum cells indicated depolarization in $\mathrm{W} / \mathrm{W}^{v}$ and $\mathrm{WT}$, but subsequently perfused $\mathrm{AH}$ had no additional effect on RMP. AH inhibited the voltage-dependent $\mathrm{K}^{+}$currents of acutely isolated mouse jejunum smooth muscle cells. Our study demonstrate that $\mathrm{AH}$ enhances the contraction activity of jejunum smooth muscle, an effect which is mediated by voltage-dependent potassium channels that acts to enhance the excitability of jejunum smooth muscle cells in mice.
\end{abstract}

\section{Key words}

Arecoline hydrobromide - Gastrointestinal motility • W/W $\bullet$ Voltage-dependent potassium channels

\section{Corresponding author}

Z. Chen, Guangdong Provincial Hospital of T.C.M, No. 111 Dade Road, Guangzhou, 510120, China. E-mail: wssq@gzucm.edu.cn

\section{Introduction}

Under physiological conditions, rhythmic depolarization waves (also known as slow waves) are observed in gastrointestinal smooth muscle tissue. It was previously believed that gastrointestinal contractions were generated by action potentials superimposed on slow waves (Sanders et al. 2016). However, the work of both Sanders and Huizinga demonstrated that, slow wave activity is abolished, while scattered action potentials persist in $\mathrm{W} / \mathrm{W}^{\mathrm{v}}$ which lack of c-kit-positive interstitial cells of Cajal (ICC) (Hulzinga et al. 1995, Ward et al. 1994). Other studies have shown that $\mathrm{W} / \mathrm{W}^{\mathrm{v}}$ exhibit irregular action potentials and small intestinal tissue contractions in addition to decreases in both gastrointestinal contraction coordination and intestinal propulsion (Der-Silaphet et al. 1998). Smooth muscle cells (SMCs) receive electrical signals from the intestinal nervous system and interstitial cells. Based on these inputs, the SMCs are stimulated to either contract or relax, thereby regulating gastrointestinal motility (Sung et al. 2015). The excitability of these SMCs is closely related to the ion channels present on their cell membranes. For example, potassium channel activity contributes to the maintenance of membrane hyperpolarization in SMCs. This reduces cell excitability, ultimately promoting smooth muscle relaxation (Haick 
and Byron 2016). When voltage-gated potassium channels are inhibited, the resultant membrane depolarization can induce the activation of L-type calcium channels, resulting in action potential-induced contractions (Chang 2005, Sanders et al. 2012, McClain et al. 2015). Therefore, it is of great physiological and pathophysiological significance to study the relationship between voltage-gated potassium channels and smooth muscle motility in gastrointestinal SMCs.

Our previous studies have shown that oral consumption of areca nut water extract by healthy volunteers can increase gastrointestinal motility by enhancing electrogastrogram parameters (Sun et al. 2016). Arecoline is the main active ingredient found in the areca nut. The arecoline content in Xiangbin exceeds $2.7 \%$ (Jiang et al. 2019). We also found that arecoline enhances gastrointestinal muscle strip contraction in rats through the activation of muscarinic receptors (Zhang et al. 2016). However, it remains unclear whether arecoline regulates gastrointestinal motility by modulating SMC excitability through voltage-gated potassium channels.

Because of the absence of slow wave behaviors in $\mathrm{W}$ mutant mice small intestine, only stable resting membrane potential (RMP) of SMC (Hulzinga et al. 1995, Ward et al. 1994). Therefore, this may be a good model system for studying the basic excitability of small intestinal SMCs. In this study, $\mathrm{W} / \mathrm{W}^{\mathrm{v}}$ were used to assess the effects of jejunum contraction and resting membrane potential on arecoline hydrobromide $(\mathrm{AH})$ promoting gastrointestinal motility.

\section{Methods}

\section{Animals}

$\mathrm{W} / \mathrm{W}^{\mathrm{v}}$ and WT mice aged 8-12 weeks (20-25 g) were provided by Jackson Laboratory (USA) and fed in Guangdong Experimental Animal Center. The mice were housed at a constant temperature $\left(20-25^{\circ} \mathrm{C}\right)$ under a $12 \mathrm{~h}$ light/dark cycle with free access to water and food.

\section{Ethics}

The protocol was approved by the Committee on the Ethics of Animal Experiments (No. 2014017-3). Animals were treated in accordance with Guide for the Care and Use of Laboratory Animals $\left(8^{\text {th }}\right.$ edition, National Academies Press). All surgeries were performed with isoflurane, and all efforts were made to minimize animal suffering.
Tissue preparation and tension measurement of muscle strips

The mice were initially anesthetized with isoflurane before being killed by cervical dislocation. The jejunum, found $5-10 \mathrm{~cm}$ above the ileocecal region, was removed quickly and placed in Krebs solution (121.9 mM $\mathrm{NaCl}, 15.5 \mathrm{mM} \mathrm{NaHCO} 3,5.9 \mathrm{mM} \mathrm{KCl}, 1.2 \mathrm{mM} \mathrm{MgSO}_{4}$, $1.2 \mathrm{mM} \mathrm{KH}_{2} \mathrm{PO}_{4}, 11.5 \mathrm{mM}$ glucose, and $2.5 \mathrm{mM} \mathrm{CaCl}_{2}$ ) which aerated $\left(95 \% \mathrm{O}_{2}\right.$ and $\left.5 \% \mathrm{CO}_{2}\right)$. The jejunum was cut along the mesentery, washed with ice-cold Krebs solution with the mucosa facing upward, after removed the mucosa and submucosa. All thickness muscle strips ( $2 \mathrm{~mm} \times 8 \mathrm{~mm}$ ) were taken along the longitudinal axis of intestine. The strips were hung in the $10 \mathrm{ml}$ organ baths perfused with $37^{\circ} \mathrm{C}$ Krebs solution. Mechanical activity of jejunum smooth muscle was recorded by an isometric force transducer (multi-chamber Organ Bath Systems, Panlab, Spain).

\section{Intracellular microelectrode recording}

Full-thickness muscle strips $(8 \mathrm{~mm} \times 4 \mathrm{~mm})$ were cut from the intestine and pinned onto the base of a silica layer and continuously perfused with oxygenated Krebs solution at $37^{\circ} \mathrm{C}$. Before recording, strips incubated for $2 \mathrm{~h}$. The glass microelectrodes with resistances of 50-80 M $\Omega$ were filled with $1 \mathrm{M} \mathrm{KCl}$ for piercing cells. Recording and amplifying electrical response through a high input impedance amplifier (AXON210B, Molecular Devices, USA). The data were recorded by personal computer using Clampfit 10.4.

\section{Cell preparation}

As described above, the muscularis was cut into segments after the mucosal and submucosal layers had been removed. These segments were stored in KraftBruhe (KB, $0.5 \mathrm{mM}$ EGTA, $10 \mathrm{mM}$ HEPES, $3 \mathrm{mM}$

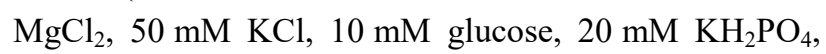
$20 \mathrm{mM}$ taurine, and $50 \mathrm{mM}$ glutamic acid) solution for $15 \mathrm{~min}$ at $4{ }^{\circ} \mathrm{C}$. They were then incubated at $37^{\circ} \mathrm{C}$ in $1 \mathrm{ml}$ of digestion medium (containing $2 \mathrm{mg}$ collagenase II, $1.5 \mathrm{mg}$ trypsin inhibitor, $500 \mu \mathrm{g}$ papain, $1.5 \mathrm{mg}$ dithiothreitol, and $3 \mathrm{mg}$ bovine serum albumin) for 10-15 min. Then discarded the supernatant, and washed the muscle segments with the modified KB solution. Tissue pieces were blowed to create a cell suspension. The freshly dispersed cells were stored in the $\mathrm{KB}$ solution at $4{ }^{\circ} \mathrm{C}$ for patch-clamp. 


\section{Voltage patch-clamp experiment}

Transferred the cell suspension to a perfusion chamber on the stage of an inverted microscope. Cells were adherent for $20 \mathrm{~min}$ before recording. The transient outward $\mathrm{K}^{+}$current $(\mathrm{IKv})$ was recorded and amplified using an AXON 700B amplifier (Molecular Devices, USA). For recording the IKv, the pipette with resistances of 3-5 M $\Omega$ was filled with a potassium ion electrode solutions. IKv was a step voltage command pulse from $-40 \mathrm{mV}$ to $+100 \mathrm{mV}$ for $400 \mathrm{~ms}$, increasing by $20 \mathrm{mV}$ at $10 \mathrm{~s}$ intervals.

Drugs

$\mathrm{AH}$ was purchased from Adamas (Adamas Reagent, Ltd., Shanghai, China). Atropine, tetraethylammonium (TEA), nicardipine and other chemicals were all acquired from Sigma (Sigma-Aldrich, St. Louis, MO, USA) unless indicated otherwise. Nicardipine was dissolved in dimethyl sulfoxide (DMSO). Other drugs were dissolved in distilled water.

\section{Statistical analysis}

The data were shown as mean \pm S.E.M.; $n$ refers to the number of animals. A Student's $t$-test was used to determine whether data sets were different, with a $P<0.05$ expressed as significant differences. Data statistics were calculated with GraphPad Prism 5 (GraphPad Software, La Jolla, USA).

\section{Results}

Effect of AH on jejunum smooth muscle contractions in $W / W^{\nu}$ and $W T$

We observed the effect of different concentrations of $\mathrm{AH}$ on jejunum smooth muscle tonic contractions in $\mathrm{W} / \mathrm{W}^{\mathrm{v}}$ and WT. When muscle strip tension was balanced, rhythmic contractions appeared in WT. However, in $\mathrm{W} / \mathrm{W}^{\mathrm{v}}$, contraction frequency was decreased and intermittent interruptions occurred randomly under normal conditions. After treatment with $\mathrm{AH}\left(10^{-8}, 10^{-7}, 10^{-6}\right.$, and $\left.10^{-5} \mathrm{M}\right)$, jejunum contractions were enhanced in a dosedependent manner in both $\mathrm{WT}$ and $\mathrm{W} / \mathrm{W}^{\mathrm{v}}$. In WT, the change of contraction amplitudes were found to be significant at the concentrations of $10^{-7}$ and $10^{-6} \mathrm{M}$ $(P=0.0166$ and 0.0188 respectively, $\mathrm{n}=6$, Fig. $1 \mathrm{~A}, \mathrm{C})$. The contraction frequency was changed from $37.4 \pm 2.5 \mathrm{cpm}$ in the control to $38.1 \pm 2.7 \mathrm{cpm}, 41.2 \pm 1.5 \mathrm{cpm}, 36.9 \pm 1.9 \mathrm{cpm}$ and $37.0 \pm 4.5 \mathrm{cpm}$ following $\mathrm{AH}\left(10^{-8}, 10^{-7}, 10^{-6}\right.$, and $10^{-5} \mathrm{M}$ ) treatments in (Fig. 1A, D). For contraction frequency in WT, there was no significant difference found at any of these concentrations as compared to the control $(P>0.05, \mathrm{n}=6$, Fig. 1A, D).
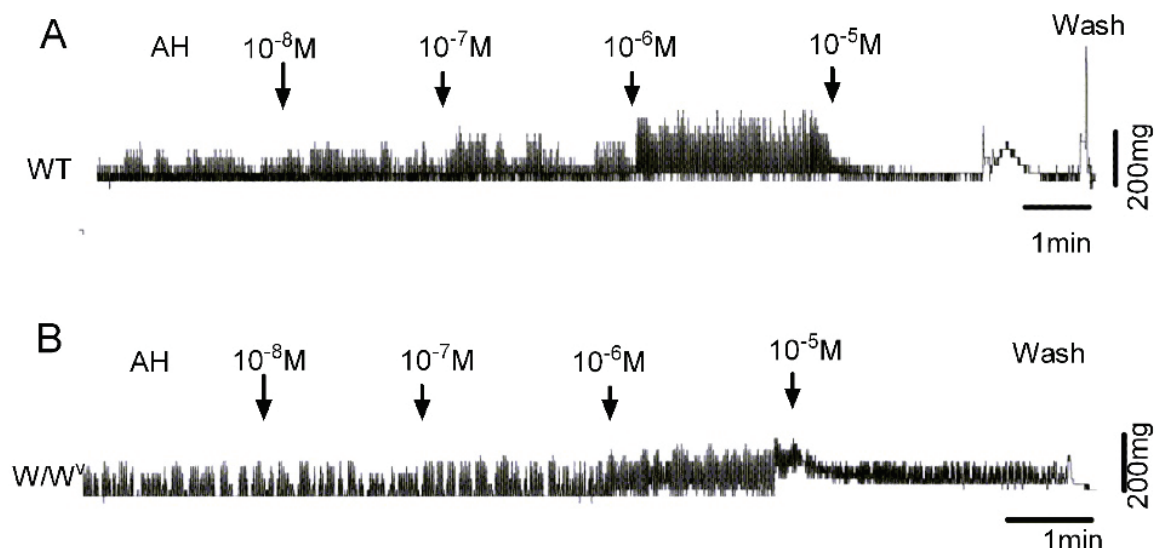

C

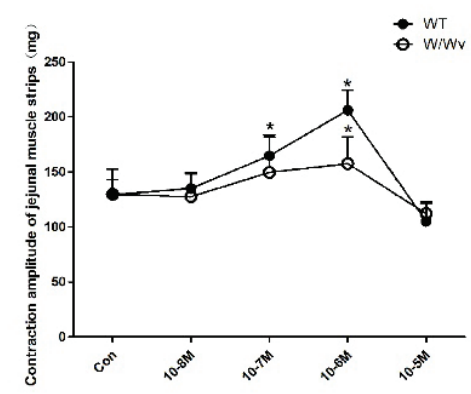

D

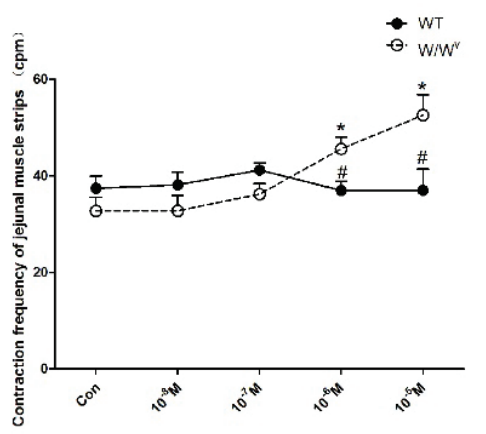

Fig. 1. Arecoline hydrobromide enhances contractions of jejunal smooth muscle strips in wild-type and $\mathrm{W} / \mathrm{W}^{\mathrm{v}}$. Representative trace of changes to jejunal smooth muscle strips induced by different concentrations $\left(10^{-8}, 10^{-7}, 10^{-6}\right.$ and $10^{-5} \mathrm{M}$ ) of arecoline hydrobromide (AH) for wild type (WT, A) and $W / W^{v}$ (B). (C) Line graph showing the effects of different concentrations of $\mathrm{AH}$ on induced contraction amplitude (C) and frequency (D) in jejunal smooth muscle from $W T$ and $W / W^{v}$. Data are expressed as mean $\pm \mathrm{SE}, \mathrm{n}=6$, * $P<0.05$, vs. the control. ${ }^{\#} P<0.05$, comparing with the same concentrations between WT and $\mathrm{W} / \mathrm{W}^{\mathrm{v}}$. 
In $\mathrm{W} / \mathrm{W}^{\mathrm{v}}$, contraction amplitude was changed from $129.6 \pm 22.9 \mathrm{mg}$ in the control to $127.4 \pm 22.0 \mathrm{mg}$, $149.5 \pm 32.3 \mathrm{mg}, 157.5 \pm 24.4 \mathrm{mg}$, and $112.1 \pm 9.2 \mathrm{mg}$ after treatment with $10^{-8}, 10^{-7}, 10^{-6}$, and $10^{-5} \mathrm{M} \mathrm{AH}$, respectively (Fig. 1B, C). The effect was significant at the $10^{-6} \mathrm{M}$ concentration $(P=0.0121, \mathrm{n}=6)$. The contraction frequency was changed from $32.7 \pm 2.8 \mathrm{cpm}$ in the control to $32.8 \pm 3.1 \mathrm{cpm}, \quad 36.2 \pm 2.2 \mathrm{cpm}, \quad 45.6 \pm 2.5 \mathrm{cpm}$ and $52.6 \pm 4.3 \mathrm{cpm}$ after treatment with $\mathrm{AH}\left(10^{-8}, 10^{-7}, 10^{-6}\right.$, and $\left.10^{-5} \mathrm{M}\right)$ (Fig. 1A, D). When compared to the control, a significant difference was found for the $10^{-6}$ and $10^{-5} \mathrm{M}$ concentrations ( $P=0.0291,0.0278$, respectively; $\mathrm{n}=6)$.

Furthermore, when we compared the effects of AH on jejunal contraction parameters between WT and $\mathrm{W} / \mathrm{W}^{\mathrm{v}}$, it was shown that contraction frequency in $\mathrm{W} / \mathrm{W}^{\mathrm{v}}$ increased significantly after the addition of $10^{-6}$ and $10^{-5} \mathrm{M} \mathrm{AH}(P=0.0200$ and 0.0299 , respectively; $\mathrm{n}=6)$.

The inhibitory effects of atropine, nicardipine and TEA on the enhancement of jejunal muscle strip contraction by AH Atropine $\left(10^{-4} \mathrm{M}\right)$ completely blocked the excitatory effect of $\mathrm{AH}\left(10^{-6} \mathrm{M}\right)$ on jejunal tonic contraction in $\mathrm{W} / \mathrm{W}^{\mathrm{v}}$ and $\mathrm{WT}$ (Fig. 2A, B). Similarly, nicardipine $\left(10^{-6} \mathrm{M}\right)$, an ${\mathrm{L}-\mathrm{Ca}^{2+}}^{2}$ channel blocker, blocked the excitatory effect of $\mathrm{AH}$ in $\mathrm{W} / \mathrm{W}^{\mathrm{v}}$ and $\mathrm{WT}$ (Fig. 2C, D). The $\mathrm{K}^{+}$channel blocker TEA could not inhibit the enhancement of $\mathrm{AH}\left(10^{-6} \mathrm{M}\right)$ in WT, but was able to block the excitatory effect of $\mathrm{AH}\left(10^{-6} \mathrm{M}\right)$ in $\mathrm{W} / \mathrm{W}^{\mathrm{v}}$. Pre-treatment with TEA $\left(10^{-4} \mathrm{M}\right)$ increased jejunal muscle strip contraction in WT. Subsequent treatment of WT with $\mathrm{AH}\left(10^{-6} \mathrm{M}\right)$ significantly enhanced the contractions of muscle strips (Fig. 2E). After treating with TEA and $\mathrm{AH}$, contraction amplitude was $241.5 \pm 16.0 \mathrm{mg}$, and contraction frequency was $37.8 \pm 1.1 \mathrm{cpm}$. As compared with TEA pre-treatment alone, contraction amplitude increased after $\mathrm{AH}$ treatment $(P=0.0002, \mathrm{n}=6)$. The different changes were observed in $\mathrm{W} / \mathrm{W}^{\mathrm{v}}$ after TEA $\left(10^{-4} \mathrm{M}\right)$ pre-treatment. Basal contraction amplitude and frequency were increased to $128.5 \pm 6.2 \mathrm{mg}$ and $34.4 \pm 1.3 \mathrm{cpm}$, respectively. However, the following treatment with $\mathrm{AH}\left(10^{-6} \mathrm{M}\right)$ did not enhance contraction amplitude $(129.9 \pm 4.7 \mathrm{mg})$ or frequency (34.9 $\pm 1.2 \mathrm{cpm})$ (Fig. $2 \mathrm{~F})$. Compared with TEA pre-treatment alone, subsequent $\mathrm{AH}$ treatment did not lead to significant changes in jejunal contraction amplitude or frequency in $\mathrm{W} / \mathrm{W}^{\mathrm{v}}$.
WT

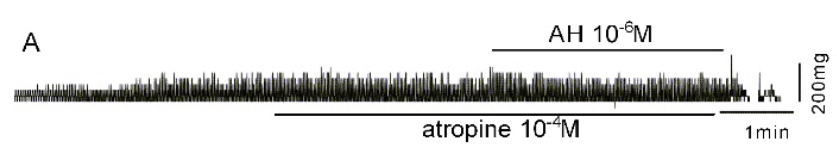

C

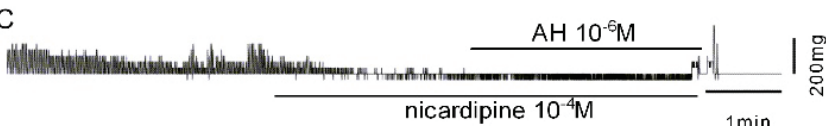

$\mathrm{E}$

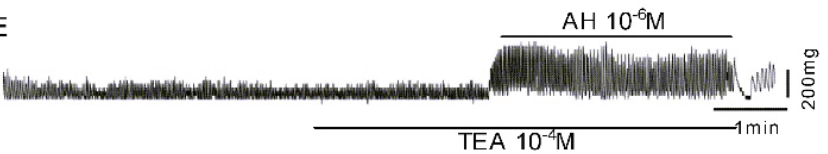

W/W
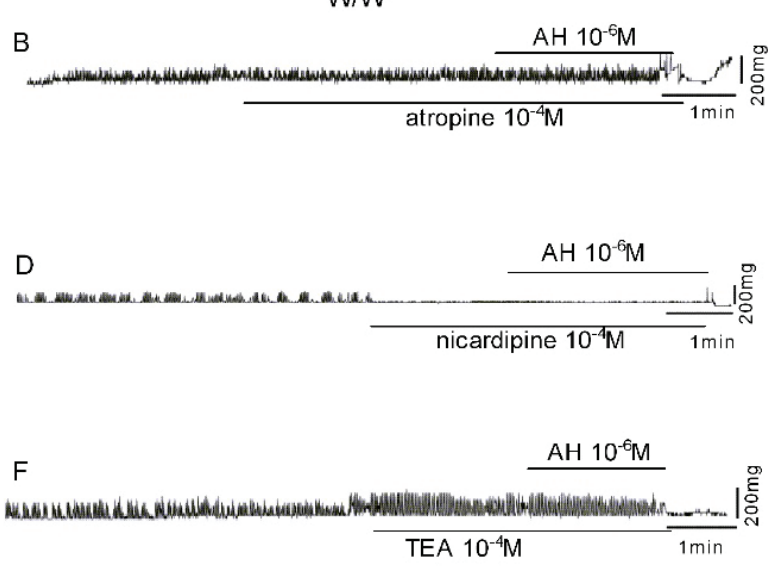

Fig. 2. Atropine, nicardipine and tetraethylammonium block arecoline hydrobromide-induced enhancement of contractions in jejunal smooth muscle from wild type and $\mathrm{W} / \mathrm{W}^{2}$. Atropine $\left(10^{-4} \mathrm{M}\right)$ pretreatment did not change the contraction amplitude and frequency of jejunal smooth muscle in wild-type $(\mathbf{A})$ and $\mathrm{W} / \mathrm{W}^{\mathrm{V}}(\mathbf{B})$. Atropine $\left(10^{-4} \mathrm{M}\right)$ significantly inhibited the enhancement of $10^{-6} \mathrm{M}$ AH on jejunal muscle strips in both WT and W/Wv. After pretreatment with nicardipine $\left(10^{-6} \mathrm{M}\right)$, the basic contraction rhythm of WT (C) and W/W $($ D) disappeared, and no muscle strip contraction was observed after continuous administration of $10^{-6} \mathrm{M} \mathrm{AH}$. (E) The contractile activity of jejunal smooth muscle strips from WT was not significantly enhanced after pretreatment with tetraethylammonium (TEA; $10^{-4} \mathrm{M}$ ). TEA $\left(10^{-4} \mathrm{M}\right)$ could not inhibit the effects of $\mathrm{AH}\left(10^{-6} \mathrm{M}\right)$ on jejunal smooth muscle in WT. (F) After pretreatment with TEA $\left(10^{-4} \mathrm{M}\right)$, the contractions increased significantly, but subsequent addition of $\mathrm{AH}\left(10^{-6} \mathrm{M}\right)$ did not increase contractions in jejunal smooth muscle strips of $\mathrm{W} / \mathrm{W}^{\mathrm{v}}$.

Effect of AH on resting membrane potential (RMP) in WT and $W / W^{\nu}$

The results showed that rhythmic slow waves with an RMP of $-63.3 \pm 1.3 \mathrm{mV}$, a frequency of
$34.2 \pm 1.8 \mathrm{cpm}$ and an amplitude of $19.0 \pm 0.8 \mathrm{mV}$ were observed in the jejunal smooth muscle of WT (Fig. 3A). After treatment with $10^{-6} \mathrm{M} \mathrm{AH}$, RMP measurements were depolarized to $-52.2 \pm 0.7 \mathrm{mV} \quad(P<0.001, \mathrm{n}=12$, 
Fig. 3Ac, B), slow wave frequency was reduced to $28.5 \pm 0.6 \mathrm{cpm}(\mathrm{p}=0.0012, \mathrm{n}=12$, Fig. $3 \mathrm{Ac}, \mathrm{C})$ and signal amplitude was reduced to $17.2 \pm 1.1 \mathrm{mV}(P=0.1962, \mathrm{n}=12$, Fig. 3Ac, D).

In jejunal muscle strips from $\mathrm{W} / \mathrm{W}^{\mathrm{v}}$, the rhythmic slow waves could be observed, and only a flat and stable resting membrane potential was recorded (Fig. 3E). After perfusion of $10^{-6} \mathrm{M} \mathrm{AH}$, the RMP increased from $-51.4 \pm 1.0 \mathrm{mV}$ to $-43.4 \pm 1.5 \mathrm{mV}$, resulting in obvious depolarization of SMCs (compared with control, $P<0.001, \mathrm{n}=12$, Fig. $3 \mathrm{Ec}, \mathrm{F})$. These results suggested that the enhancement of jejunal SMC contractions by $\mathrm{AH}$ was related to the depolarization of SMC membranes.

We found that $\mathrm{AH}\left(10^{-6} \mathrm{M}\right)$ depolarized the RMP from $-61.24 \pm 4.23 \mathrm{mV}$ in the control to $-45.22 \pm 3.31 \mathrm{mV}$ (Fig. 3A, B; $P<0.05, \mathrm{n}=6$ ). Slow wave amplitude was increased from $15.52 \pm 3.68 \mathrm{mV}$ to $20.61 \pm 4.36 \mathrm{mV}$ (Fig. $3 \mathrm{C} ; P<0.05, \mathrm{n}=6$ ). It was suggested that the excitatory effect of $\mathrm{AH}$ may be related to the depolarization of membrane potential.
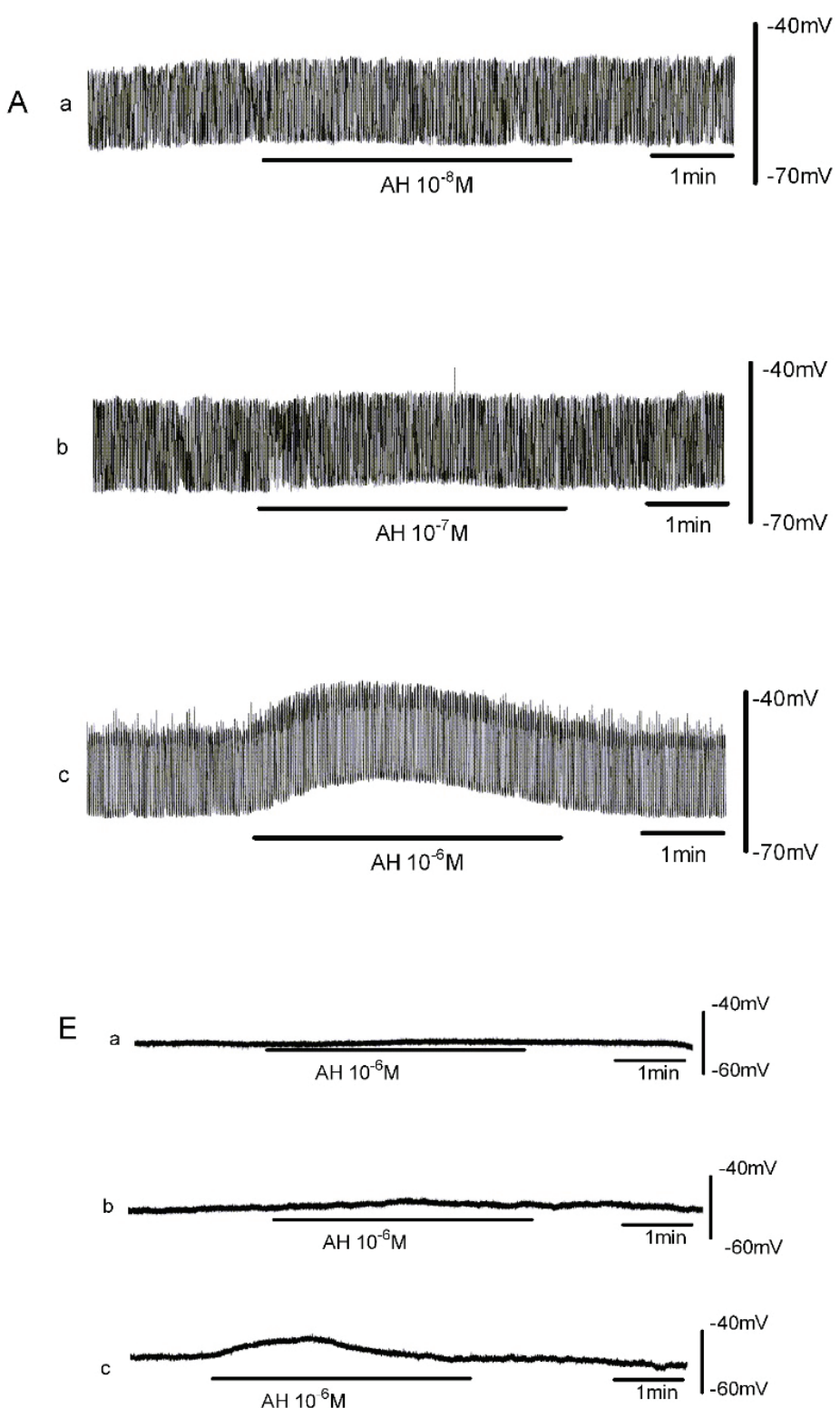
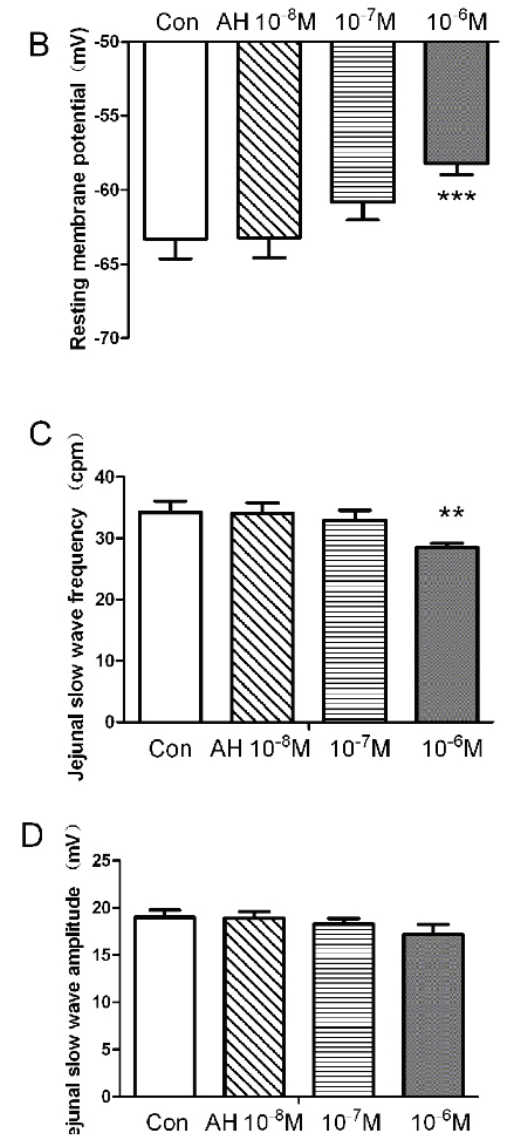

$\mathrm{F}$

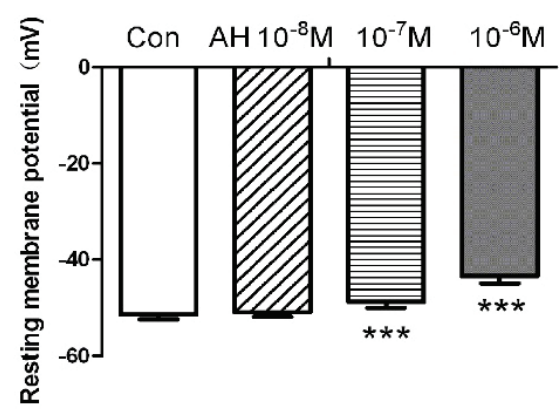

Fig. 3. Effects of arecoline hydrobromide on jejunal slow waves in wild-type and $W / W^{2}$. (A) Representative trace of changes in jejunal smooth muscle slow waves induced by $10^{-8} \mathrm{M}(\mathbf{a}), 10^{-7} \mathrm{M}(\mathbf{b})$ and $10^{-6} \mathrm{M}(\mathbf{c})$ of arecoline hydrobromide (AH) for wild-type (WT). Column chart comparing resting membrane potential (RMP, (B), frequency (C) and amplitude (D) of jejunum slow wave activity in WT. (E) Representative trace of changes in jejunal smooth muscle RMP induced by $10^{-8} \mathrm{M}(\mathbf{a}), 10^{-7} \mathrm{M}(\mathbf{b})$ and $10^{-6} \mathrm{M}$ (c) $\mathrm{AH}$ for W/W $\mathrm{W}^{v}$. Column chart comparing RMP of jejunum slow wave activity in $\mathrm{W} / \mathrm{W}^{v}$. $* * P<0.01$ and $* * * P<0.001$, vs. the control. (WT: $\mathrm{n}=12, \mathrm{~W} / \mathrm{W}^{v}: \mathrm{n}=13$ ). 
The inhibitory effect of TEA on depolarization of RMP by AH

Pretreatment with TEA $\left(10^{-4} \mathrm{M}\right)$ depolarized the jejunal SMCs of WT, increasing the RMP from $-63.7 \pm 1.7 \mathrm{mV}$ to $-52.1 \pm 1.0 \mathrm{mV}$ and slow wave amplitude from $17.3 \pm 0.7 \mathrm{mV}$ to $18.0 \pm 0.6 \mathrm{mV}$, while decreasing signal frequency from $34.9 \pm 1.9 \mathrm{cpm}$ to $31.4 \pm 1.2 \mathrm{cpm}$ (Fig. 4). After reperfusion of $10^{-6} \mathrm{M} \mathrm{AH}$, there were no further changes to RMP or slow wave frequency, but slow wave amplitude was significantly increased to $19.4 \pm 0.5 \mathrm{mV}(P=0.0012, \mathrm{n}=6$, compared with TEA pretreatment).

Similarly, pretreatment with TEA $\left(10^{-4} \mathrm{M}\right)$ could depolarize the RMP of jejunal SMCs of $\mathrm{W} / \mathrm{W}^{\mathrm{v}}$ from $-51.1 \pm 0.8 \mathrm{mV}$ to $-45.0 \pm 1.4$, while subsequent $\mathrm{AH}$ $\left(10^{-6} \mathrm{M}\right)$ perfusion could not further depolarize the RMP in $\mathrm{W} / \mathrm{W}^{\mathrm{v}}$ (Fig. 4).

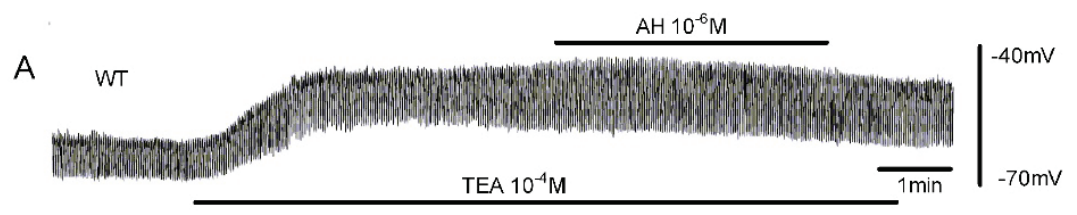

B
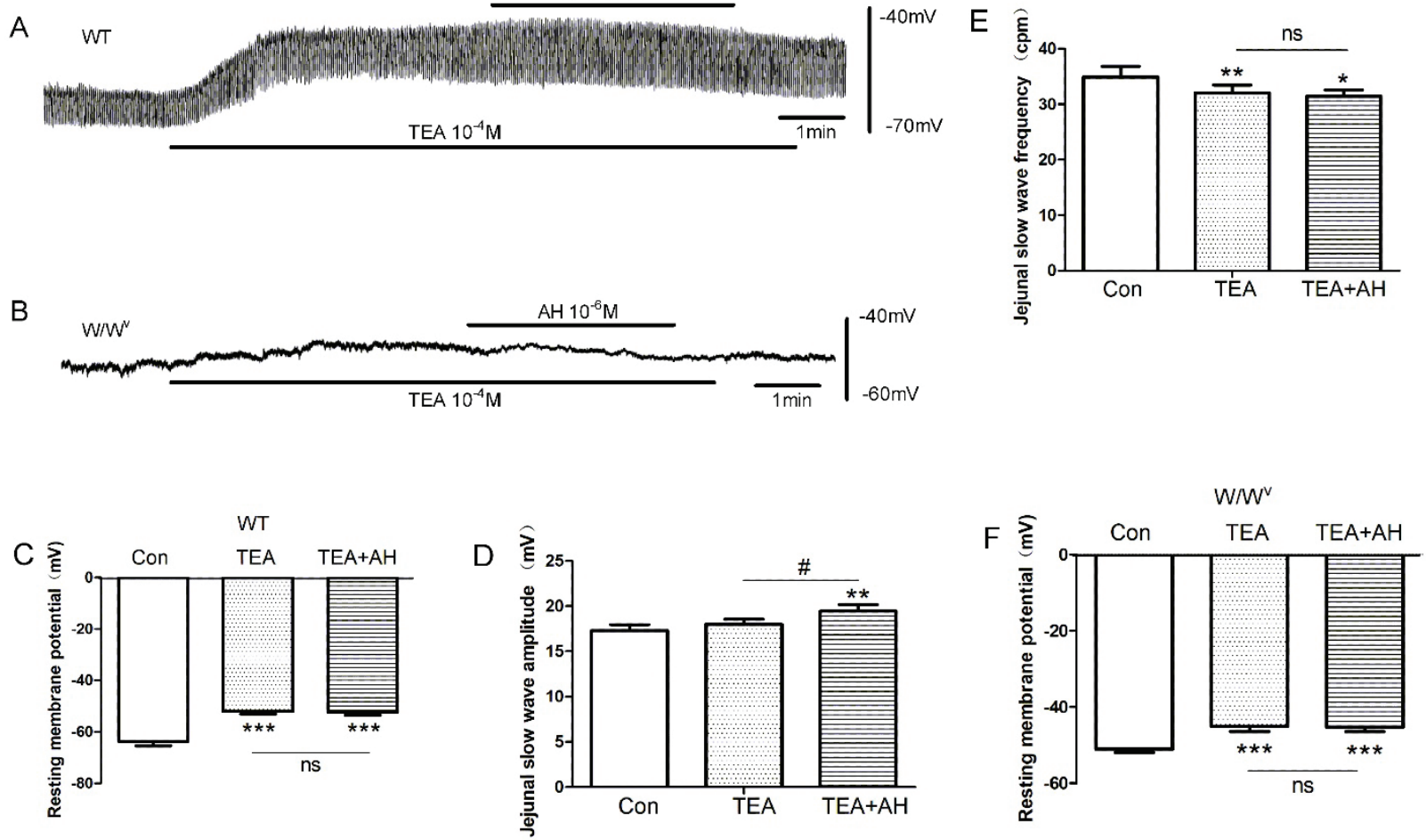

Fig. 4. TEA blocked arecoline hydrobromide-induced resting membrane potential depolarization in jejunal smooth muscle in wild-type and $\mathrm{W} / \mathrm{W}^{\mathrm{V}}$. (A) Representative trace of TEA blocking arecoline hydrobromide- (AH) induced resting membrane potential depolarization in jejunal smooth muscle from wild type (WT). Jejunal slow wave RMP was depolarized after pretreatment with TEA $\left(10^{-4} \mathrm{M}\right)$. The subsequent perfusion of $10^{-6} \mathrm{M}$ AH did not cause the RMP to depolarize further, although the amplitude of slow wave activity increased. Representative trace of TEA blocking AH-induced RMP depolarization in jejunal smooth muscle from W/Wv (B) and WT (C). As in WT, TEA inhibits AH-induced depolarization of RMP in W/W $\mathrm{W}^{v}$. After pretreatment with TEA $\left(10^{-4} \mathrm{M}\right)$ alone or treatment with both TEA (10 $\left.0^{-4} \mathrm{M}\right)$ and $\mathrm{AH}\left(10^{-6} \mathrm{M}\right)$, the RMP depolarized significantly in WT. There was no significant difference in RMP between TEA and TEA+AH treatments. Column chart of the effects of TEA and AH on slow wave amplitude (D) and frequency (E) in WT. (F) Column chart of TEA block of AH-induced RMP depolarization in the jejunum of W/W $\mathrm{W}^{\mathrm{V}}$. TEA $\left(10^{-4} \mathrm{M}\right)$ depolarized resting membrane potential and blocked the effect of the subsequent $\mathrm{AH}\left(10^{-6} \mathrm{M}\right)$. Data are expressed as mean $\pm \mathrm{SE}, \mathrm{WT}, \mathrm{n}=6 ; \mathrm{W} / \mathrm{W}^{v}, \mathrm{n}=7 . * P<0.05, * * P<0.01$, *** $P<0.001$ vs. the control; compared with TEA and TEA+AH, ${ }^{\#} P<0.05$, ns $P>0.05$.

Arecoline hydrobromide reduced voltage-gated potassium current in jejunal SMCs

As shown previously, AH depolarized the RMP. Therefore, we further tested the IKv for the effect of $\mathrm{AH}$. Freshly dispersed intestinal SMCs were used for wholecell patch clamp IKv recording. The mean peak current decreased from $1425.8 \pm 50.6 \mathrm{pA}$ in the control to $1289.6 \pm 32.5 \mathrm{pA}, \quad 1019.1 \pm 40.8 \mathrm{pA}$, and $855.0 \pm 37.2 \mathrm{pA}$ after treatment with $10^{-7}, 10^{-6}$, and $10^{-5} \mathrm{M} \mathrm{AH}$, respectively (Fig. 5A, B; all $P<0.01, \mathrm{n}=9$ ). A step voltage command was used to determine the effect of $10^{-6} \mathrm{M} \mathrm{AH}$ on the current-voltage (I-V) relationship of $\mathrm{IKv}$. Treatment with $10^{-6} \mathrm{M}$ AH significantly decreased the I-V curve of IKv at each tested (Fig. 5C). The IKv at $+40 \mathrm{mV}$ was decreased by $23.9 \pm 5.5 \%$ (Fig. $5 \mathrm{C}, P<0.05$, $\mathrm{n}=9$ ) with $10^{-6} \mathrm{M} \mathrm{AH}$. It suggested that IKv may be involved in AH-induced jejunal smooth muscle RMP depolarization in mice. 
A
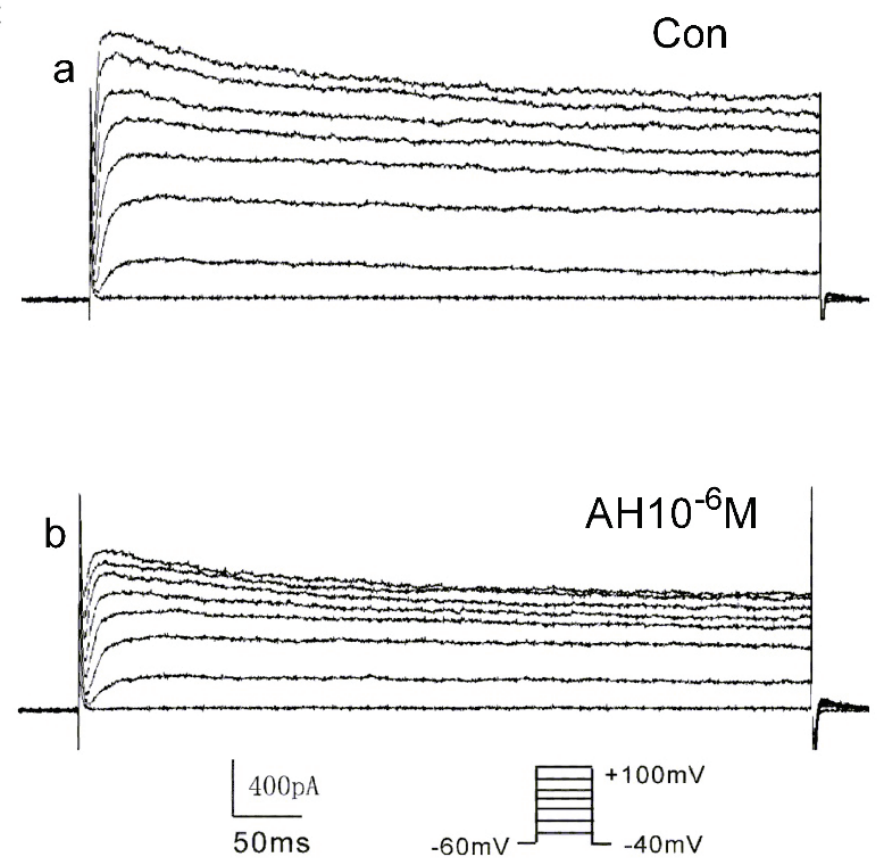

B
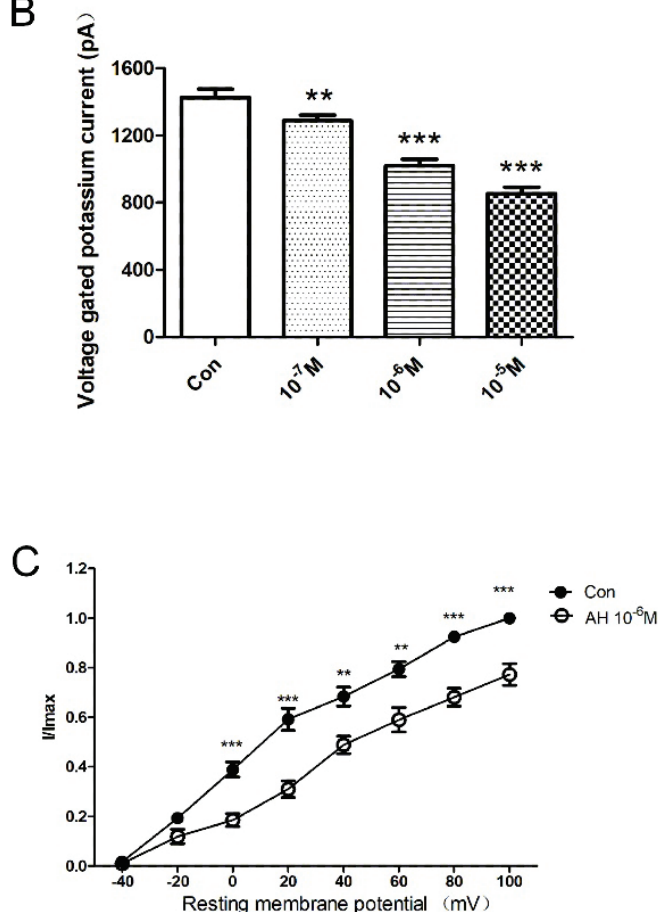

Fig. 5. Effects of arecoline hydrobromide on voltage-gated potassium currents in murine jejunal smooth muscle cells. (A) Representative trace of arecoline hydrobromide (AH) reducing activity of voltage gated potassium currents (IKv). (a) Control, (b) $\mathrm{AH}\left(10^{-6} \mathrm{M}\right)$. (B) $10^{-7}, 10^{-6}$ and $10^{-5} \mathrm{M}$ AH dose-dependently decreased IKv. (C) The I-V relationship curve of the AH-induced change in IKv. Data are expressed as mean $\pm \mathrm{SE}, * * P<0.01, * * * P<0.001, \mathrm{n}=9$, vs. the control.

\section{Discussion}

ICCs are located in the gastrointestinal tract in many mammals and produce a rhythmic depolarization potential and slow wave activity (Hyun et al. 2009, Wang et al. 2018, Drumm et al. 2018). ICCs respond to stimulation by exogenous nerves or gastrointestinal hormones and generate slow waves through the activity of CaCC channels (Hwang et al. 2019). SMCs receive slow waves produced by ICCs through gap junctions and, in response, activate voltage-dependent $\mathrm{L}-\mathrm{Ca}^{2+}$ channels (Kim et al. 2008, Jin et al. 2002). These currents generate action potentials, which allow calcium influx and support the contraction of SMCs (Thornbury et al. 2011). In this study, AH did not significantly alter the contraction frequencies of slow wave and mechanical activity in wild mice. In contrast, high concentrations of $\mathrm{AH}$ increased the contraction frequency of jejunal smooth muscle in $\mathrm{W} / \mathrm{W}^{\mathrm{v}}$. Therefore, the frequency of mechanical contraction is the same as that of slow wave activity in WT. However, as there were no slow waves in $\mathrm{W} / \mathrm{W}^{\mathrm{v}}$ jejunal cells, the triggering of action potentials was determined only by the excitability of the SMCs themselves. After the excitation of SMCs, the probability of calcium channels opening was increased.
Voltage-dependent potassium channels play a key role in establishing the resting membrane potential of gastrointestinal smooth muscle, and it is the main ion channel responsible for maintaining a stable resting membrane potential (Nagasaki et al. 1993, Hashitani et al. 2005). Resting membrane potential depolarization of SMCs can increase the opening probability of $\mathrm{Ca}^{2+}$ channels (Rich et al. 1993, Gibbons et al. 2009). A small depolarization can re-stimulate $\mathrm{Ca}^{2+}$ channels, which can then generate an action potential. The number and frequency of action potentials are determined by $\mathrm{K}^{+}$channels (Koh et al. 1999). Therefore, we observed the effects of IKV-specific blocker TEA on AH treatment of jejunal smooth muscle in wild and $\mathrm{W} / \mathrm{W}^{\mathrm{v}}$ (Fig. 2). These results showed that TEA could block the effect of AH on jejunal smooth muscle of $\mathrm{W} / \mathrm{W}^{\mathrm{v}}$, but not on that of WT. Subsequent experiments showed that AH can depolarize RMP of jejunal SMCs, and inhibit the voltagegated potassium currents in SMCs. Rhythmic slow waves exist in jejunal smooth muscle of wild mice and are essential for excitation-contraction coupling (Kito 2011). $\mathrm{L}-\mathrm{Ca}^{2+}$ channels open at the slow wave plateau stage, which allows extracellular $\mathrm{Ca}^{2+}$ to enter cells and participate in the excitation-contraction process (Rich et al. 1993, Kovac et al. 2005). Therefore, the excitability 
of jejunum SMCs in WT is mainly determined by the normal ICC network structure and slow wave activity. In contrast, slow waves were not found in the jejunum of $\mathrm{W} / \mathrm{W}^{\mathrm{v}}$, where the excitability of SMCs is closely related to their resting membrane potential. TEA blocks potassium channels, which resulted in depolarization of SMCs and slightly increased contraction of muscle strips. However, it also reduced the opening of potassium channels, further limited the recovery of excitability in SMCs, and eventually abolished the excitatory effect of $\mathrm{AH}$ on contractions of jejunal smooth muscle in $\mathrm{W} / \mathrm{W}^{\mathrm{v}}$.

The mechanical digestion of food depends on the motility of the gastrointestinal tract, including peristalsis and segmental movement. As smooth muscle is the main participant in gastrointestinal motility, the excitability of smooth muscle itself is the basis of gastrointestinal motility (Huizinga et al. 2014). SMCs make up to final link of excitation-contraction coupling, such that the change in SMC tension depends on the total influence of external factors (Sanders 2008). AH promotes jejunal smooth muscle contraction by inhibiting voltage-gated potassium channels and increasing the excitability of SMCs in $\mathrm{W} / \mathrm{W}^{\mathrm{v}}$, which lack ICCs. Many digestive tract diseases have been associate with structural damage of the ICC network, which leads to abnormal slow wave activity and gastrointestinal motility disorders (Cipriani et al. 2018, Jang et al. 2018, Gamage et al. 2018). The regulation of smooth muscle motion by nerves and ICCs through gap junction is greatly weakened when the ICC network structure is destroyed. In this state, the contractile function of smooth muscle itself becomes more critical. Therefore, understanding the excitability of resting membrane potential in SMCs may be helpful for the treatment of ICCs abnormalities, especially neuromuscular dysfunction.

In conclusion, we observed that $\mathrm{AH}$ depolarized the resting membrane potential of jejunum muscle cells in $\mathrm{W} / \mathrm{W}^{\mathrm{v}}$ by acting through voltage-gated potassium channels, thereby enhancing the jejunal motility of mice.

\section{Conflict of Interest}

There is no conflict of interest.

\section{Acknowledgements}

This study was supported by Traditional Chinese Medicine Bureau of Guangdong Province (20181103) and the Specific Research Fund for TCM Science and Technology of Guangdong Provincial Hospital of Chinese Medicine (YN2016QJ18, YN10101902). National Regional Traditional Chinese Medicine (Specialist) Clinic Construction [(2018)205].

\section{References}

CHANG FY: Electrogastrography: basic knowledge, recording, processing and its clinical applications. J Gastroenterol Hepatol 20: 502-516, 2005. https://doi.org/10.1111/j.1440-1746.2004.03751.x

CIPRIANI G, GIBBONS SJ, MILLER KE, YANG DS, TERHAAR ML, EISENMAN ST, ÖRDÖG T, LINDEN DR, GAJDOS GB, SZURSZEWSKI JH, FARRUGIA G: Change in populations of macrophages promotes development of delayed gastric emptying in mice. Gastroenterology 154: 2122-2136.e12, 2018. https://doi.org/10.1053/j.gastro.2018.02.027

DER-SILAPHET T, MALYSZ J, HAGEL S, LARRY ARSENAULT A, HUIZINGA JD: Interstitial cells of Cajal direct normal propulsive contractile activity in the mouse small intestine. Gastroenterology 114: 724-736, 1998. https://doi.org/10.1016/S0016-5085(98)70586-4

DRUMM BT, SUNG TS, ZHENG H, BAKER SA, KOH SD, SANDERS KM: The effects of mitochondrial inhibitors on $\mathrm{Ca} 2+$ signalling and electrical conductances required for pacemaking in interstitial cells of Cajal in the mouse small intestine. Cell Calcium 72: 1-17, 2018. https://doi.org/10.1016/j.ceca.2018.01.003

GAMAGE PPKM, PATEL BA, YEOMAN MS, RANSON RN, SAFFREY MJ: Interstitial cell network volume is reduced in the terminal bowel of ageing mice. J Cell Mol Med 22: 5160-5164, 2018. https://doi.org/10.1111/jcmm.13794

GIBBONS SJ, STREGE PR, LEI S, ROEDER JL, MAZZONE A, OU Y, RICH A, FARRUGIA G: The alpha1H Ca2+ channel subunit is expressed in mouse jejunal interstitial cells of Cajal and myocytes. J Cell Mol Med 13: 4422-4431, 2009. https://doi.org/10.1111/j.1582-4934.2008.00623.x

HAICK JM, BYRON KL: Novel treatment strategies for smooth muscle disorders: Targeting Kv7 potassium channels. Pharmacol Ther 165: 14-25, 2016. https://doi.org/10.1016/j.pharmthera.2016.05.002 
HASHITANI H, GARCIA-LONDOÑO AP, HIRST GD, EDWARDS FR: A typical slow waves generated in gastric corpus provide dominant pacemaker activity in guinea pig stomach. J Physiol 569: 459-465, 2005. https://doi.org/10.1113/jphysiol.2005.097907

HUIZINGA JD, CHEN JH, ZHU YF, PAWELKA A, MCGINN RJ, BARDAKJIAN BL, PARSONS SP, KUNZE WA, WU RY, BERCIK P, KHOSHDEL A, CHEN S, YIN S, ZHANG Q, YU Y, GAO Q, LI K, HU X, ZARATE N, COLLINS P, PISTILLI M, MA J, ZHANG R, CHEN D: The origin of segmentation motor activity in the intestine. Nat Commun 5: 3326, 2014. https://doi.org/10.1038/ncomms4326

HUIZINGA JD, THUNEBERG L, KLÜPPEL M, MALYSZ J, MIKKELSEN HB, BERNSTEIN A: W/kit gene required for interstitial cells of Cajal and for intestinal pacemaker activity. Nature 373: 347-349, 1995. https://doi.org/10.1038/373347a0

HWANG SJ, PARDO DM, ZHENG H, BAYGUINOV Y, BLAIR PJ, FORTUNE-GRANT R, COOK RS, HENNIG GW, SHONNARD MC, GRAINGER N, PERI LE, VERMA SD, ROCK J, SANDERS KM, WARD SM: Differential sensitivity of gastric and small intestinal muscles to inducible knockdown of anoctamin 1 and the effects on gastrointestinal motility. J Physiol 597: 2337-2360, 2019. https://doi.org/10.1113/JP277335

JANG DE, BAE JH, CHANG YJ, LEE YH, NAM KT, KIM IY, SEONG JK, LEE YC, YEOM SC: Neuronal nitric oxide synthase is a novel biomarker for the interstitial cells of Cajal in stress-induced diarrhea-dominant irritable bowel syndrome. Dig Dis Sci 63: 619-627, 2018. https://doi.org/10.1007/s10620-018-4933-7

JIANG SW, ZHENG ZL, XU FF, CHEN WY, TANG LP, CHEN ZQ, LIU B, LI B: Simultaneous determination of four alkaloid components in Xiangbin decoction by UPLC-QqQ-MS/MS. (In Chinese) Chin J Exp Tradit Med Formul 25: 152-159, 2019.

JIN X, MORSY N, SHOEB F, ZAVZAVADJIAN J, AKBARALI HI: Coupling of M2 muscarinic receptor to L-type Ca channel via c-src kinase in rabbit colonic circular smooth muscle. Gastroenterology 123: 827-834, 2002. https://doi.org/10.1053/gast.2002.35388

KIM YC, SUZUKI H, XU WX, HASHITANI H, CHOI W, YUN HY, PARK SM, YOUN SJ, LEE SJ, LEE SJ: Voltage-dependent Ca current identified in freshly isolated interstitial cells of Cajal (ICC) of Guinea-pig stomach. Korean J Physiol Pharmacol 12: 323-330, 2008. https://doi.org/10.4196/kipp.2008.12.6.323

KITO Y: The functional role of intramuscular interstitial cells of Cajal in the stomach. J Smooth Muscle Res 47: 47-53, 2011. https://doi.org/10.1540/jsmr.47.47

KOH SD, WARD SM, DICK GM, EPPERSON A, BONNER HP, SANDERS KM, HOROWITZ B, KENYON JL: Contribution of delayed rectifier potassium currents to the electrical activity of murine colonic smooth muscle. J Physiol 515: 475-487, 1999. https://doi.org/10.1111/j.1469-7793.1999.475ac.x

KOVAC JR, PREIKSAITIS HG, SIMS SM: Functional and molecular analysis of L-type calcium channels in human esophagus and lower esophageal sphincter smooth muscle. Am J Physiol Gastrointest Liver Physiol 289: G998-G1006, 2005. https://doi.org/10.1152/ajpgi.00529.2004

LEE HT, HENNIG GW, PARK KJ, BAYGUINOV PO, WARD SM, SANDERS KM, SMITH TK: Heterogeneities in ICC Ca2+ activity within canine large intestine. Gastroenterology 136: 2226-2236, 2009. https://doi.org/10.1053/j.gastro.2009.02.060

MCCLAIN JL, FRIED DE, GULBRANSEN BD: Agonist-evoked $\mathrm{Ca}(2+)$ signaling in enteric glia drives neural programs that regulate intestinal motility in mice. Cell Mol Gastroenterol Hepatol 1: 631-645, 2015. https://doi.org/10.1016/j.jemgh.2015.08.004

NAGASAKI M, KOMORI S, TAMAKI H, OHASHI H: Effect of trimebutine on K+ current in rabbit ileal smooth muscle cells. Eur J Pharmacol 235: 197-203, 1993. https://doi.org/10.1016/0014-2999(93)90137-7

RICH A, KENYON JL, HUME JR, OVERTURF K, HOROWITZ B, SANDERS KM: Dihydropyridine-sensitive calcium channels expressed in canine colonic smooth muscle cells. Am J Physiol 264: C745-C754, 1993. https://doi.org/10.1152/ajpcell.1993.264.3.C745

SANDERS KM, WARD SM, HENNIG GW: Problems with extracellular recording of electrical activity in gastrointestinal muscle. Nat Rev Gastroenterol Hepatol 13: 731-741, 2016. https://doi.org/10.1038/nrgastro.2016.161

SANDERS KM, KOH SD, RO S, WARD SM: Regulation of gastrointestinal motility--insights from smooth muscle biology. Nat Rev Gastroenterol Hepatol 9: 633-645, 2012. https://doi.org/10.1038/nrgastro.2012.168 
SANDERS KM: Regulation of smooth muscle excitation and contraction. Neurogastroenterol Motil 1: 39-53, 2008. https://doi.org/10.1111/j.1365-2982.2008.01108.X

SUN J, CAO LX, CHEN QC, JIANG Z, CHEN ZQ: Effect of semen arecae on multichannel electrogastrogram and motilin and corticotropin-releasing hormone levels of healthy people. (In Chinese) Trad Chin Drug Res Clin Pharm 27: 281-285, 2016.

SUNG TS, KIM HU, KIM JH, LU H, SANDERS KM, KOH SD: Protease-activated receptors modulate excitability of murine colonic smooth muscles by differential effects on interstitial cells. J Physiol 593: 1169-1181, 2015. https://doi.org/10.1113/jphysiol.2014.285148

THORNBURY KD, HOLLYWOOD MA, MCHALE NG, SERGEANT GP: Cajal beyond the gut: interstitial cells in the urinary system--towards general regulatory mechanisms of smooth muscle contractility? Acta Gastroenterol Belg 74: 536-542, 2011.

WANG TH, DU P, ANGELI TR, PASKARANANDAVADIVEL N, ERICKSON JC, ABELL TL, CHENG LK, O'GRADY G: Relationships between gastric slow wave frequency, velocity, and extracellular amplitude studied by a joint experimental-theoretical approach. Neurogastroenterol Motil 30: e13152, 2018. https://doi.org/10.1111/nmo.13152

WARD SM, BURNS AJ, TORIHASHI S, SANDERS KM: Mutation of the proto-oncogene c-kit blocks development of interstitial cells and electrical rhythmicity in murine intestine. J Physiol 480: 91-97, 1994. https://doi.org/10.1113/jphysiol.1994.sp020343

ZHANG JH, CAO LX, DENG SG, CHEN QC, JIANG Z, CHEN ZQ, ZHOU L: The effect of Arecoline hydrobromide on gastric smooth muscle strips motility in rats. (In Chinese) Guangdong Med J 19: 2881-2885, 2016. 